\title{
1. Introduction to the Handbook on Tourism and China
}

Songshan (Sam) Huang and Ganghua Chen

\section{TOURISM AND CHINA: AN INTRODUCTION}

Never in history have we seen tourism in China as such a significant economic sector, with such social force and political leverage, and with China in such a 'grand' context of tourism in the world. Juxtaposing tourism with China seems absurd but the relationship between tourism as a socio-economic phenomenon and China as a sovereign country and culture among other denominations and interpretations, does require further critical thinking.

Tourism has been understood from multiple perspectives and has different meanings for different knowledge stakeholders if put in the context of academic knowledge creation and dissemination. The United Nations World Tourism Organization (UNWTO) defines tourism as:

the activity of people temporarily away from their usual environment for a period not exceeding 1 year, and for virtually any purpose of travel, with the following exceptions: persons visiting a place for the purpose of earning money during their visit and students in long-term programs, ... members of diplomatic corps and members of the military while travelling in their official capacity, ... refugees and nomads. (Smith, 2017, p. 1)

The UNWTO definition serves as a key reference point from which to understand what tourism is. However, tourism seems to share the same level of complexity as any other words in English with an -ism suffix. Thus, in reality, there are various versions of understanding of tourism by different parties or agencies serving different purposes. In the academic field, it is not unusual to spot as many versions of definitions of tourism. Zhang (2008), in his search for the essence of tourism, identified a total of 30 definitions. Even the UNWTO definition is not closely adhered to by some government organizations in some countries. It is common to see some tourism authorities count international students as 'tourists' in their tourism statistics (Tourism Research Australia, 2019; Tourism WA, 2019).

For its multifaceted meanings, social constructions and interpretations, tourism has attracted multidisciplinary inputs from the inception of its establishment as a higher learning subject and then a field of research (Jafari and Ritchie, 1981). The study of tourism involves multiple disciplines, including economics, sociology, psychology, geography, anthropology, ecology, education, law, business, marketing, and so on (Jafari and Ritchie, 1981). In the study of tourism, multiple research paradigms are observed (Tribe, 2001), although in research practice some paradigms may be more dominant than others depending on the underlying mechanisms of the knowledge creation system (Foucault, 1980; Tribe, 2006). 


\section{Handbook on tourism and China}

While tourism provides a multidisciplinary, multi-paradigm field of academic study, when examined in the context of China tourism becomes an even more complex field of inquiry. Generally speaking, the scholarship in tourism as a knowledge field has been mostly dominated by the Western tradition of scientism (Sorell, 2013). Even within the Western epistemic sphere, alternative perspectives and paradigms appear to desperately compete for their position (Ateljevic, Morgan and Pritchard, 2012). Scholars may justify the propagation of studies that take China as the study context as due to China's increasing preponderance in the world's tourism industry and the increasing number of tourism researchers in China. While this is largely true, adding to the trend of China's increasing contribution to tourism knowledge is that China also represents a paradigmatically distinctive knowledge context, which prompts us to apply more critical contemplations on the issues intersecting tourism and China.

China is one of the few long-lasting civilizations in the world. The philosophies and their practical tenets in directing an average human-being's life have been largely preserved in the evolution of this civilization. Although there are disruptions here and there throughout its history, the vitality of this civilization is witnessed in its own way of growing out of any external threat and accommodating the new revolutionary forces of the world. It is the authors' view that while China has duly learnt lessons of its own to know the world better, the world (or more exactly, the world dominated by Western ideologies and philosophies) has yet to understand China better.

For the sake of conceptual clarity, in this book we use 'tourism and China' to widely refer to all tourism phenomena related to China (in China, to China, and from China), and cover our understanding and explanations of China-related tourism phenomena from unique perspectives rooted in the Chinese cultural, political, societal and economic settings. The word 'and' is used to demonstrate the various possible relationships and interplays between tourism and China.

\section{TOURISM AS A FIELD OF KNOWLEDGE AND A RESEARCH CONTEXT}

Under such a premise, when talking about tourism and China, we need to duly acknowledge the contextual complexities. On one hand, tourism often serves as a research context and researchers can put their research problems in this context and apply theories from multiple relevant disciplines to resolve the problems, and ultimately advance knowledge. Researchers, whether they identify themselves within the field of tourism or outside, are yet to build their confidence in tourism and see tourism as a knowledge field. Currently, though, it is estimated that there are over 100 decent academic journals on tourism (McKercher and Tung, 2015) and many publishers see tourism as the field that needs more texts. If tourism is a context, rather than a discipline (Tribe, 1997), can we still see tourism as a field of knowledge that can make its distinctive contributions to knowledge? Some tourism scholars wish to see studies in tourism reveal knowledge that can spill over to other fields. To what extent tourism has emerged as a distinctive field of knowledge is yet to be further disclosed by some dedicated bibliographical studies. But anecdotal evidence shows that some journals in the field of tourism, such as Tourism Management and Annals of Tourism Research, have attracted submissions from researchers outside the tourism academy. 


\section{CHINA: IS IT ANOTHER CONTEXT?}

If tourism serves as a context for knowledge exploration, China would serve as a context for studying tourism, imposing on the inquiries multiple philosophical, paradigmatic and epistemological lenses. The uniqueness of China as a cultural sphere actually poses paradigm challenges to tourism researchers. Can China as a unique context engender completely new knowledge derived by the context, or is China yet another context in which existing (Western) theories can find their application? We observed that while Chinese indigenous researchers tend to justify the value of their research by the unique Chinese cultural idiosyncrasies, Western culture researchers would seek to view China as yet another context from which to confirm or refute Western theories. Thus, with regard to scholarship of tourism and China, the main players and gatekeepers are not unified in their views and understandings around what constructs true knowledge.

Clearly, there is a need to examine Chinese cultural roots to understand tourism scholarship around China, Chineseness, and Chinese tourists. Relating to Urry's (2002) theory of tourist gaze, $\mathrm{Li}(2008$, p. 508) states that:

for Chinese visitors to the newly developed and newly accessible, if ancient, tourism sites all over China there is a Chinese tourist gaze that is different from the predominantly western-oriented Eurocentric tourist gaze(s) that Urry proposes (2002). In looking further into this Chinese tourist gaze, while there is support for Urry's basic notion that there is a tourist gaze that is distinct from the 'everyday gaze' of work and home (2002:2), it is suggested that for much travel by Chinese in China in contrast to travel to destinations outside China, this binary distinction of gaze for Chinese is not as great as Urry proposes. Travel for recreational purposes by Chinese in China is indeed 'away'; but it is also to 'home' in the sense of connecting with the homeland, the motherland, the very roots of Chineseness.

Culture serves as the 'software' that programs an individual's mind and behaviours (Hofstede, 1980; Hsu and Huang, 2016). Research has demonstrated that culture explains a significant proportion of tourist behaviours (Huang and Crotts, 2019; Wen, Huang and Ying, 2019). Following this logic, the emerging enormous scale of the Chinese tourist market and its numerous niches requires dedication to Chinese cultural roots in understanding Chinese tourist behaviours. Although a growing number of tourist behavioural studies involving Chinese tourists can be found, the underlying paradigm seems to follow the Western 'mainstream' approaches. For instance, motivations of Chinese tourists in visiting different types of destinations and consuming different nature tourism attractions have been examined, assuming that Chinese tourists may have different motivations in these tourism contexts (e.g., Li and Ryan, 2015; Ying and Wen, 2019). However, how Chinese cultural values can collectively explain these motivations is not clear. An ethnocentric perspective in studying Chinese tourist behaviours warrants more awareness.

Cultural determination and explanation also permeate other aspects of the tourism system (Leiper, 1979). In China, tourism forms may have rich cultural connotations. For instance, 'donkey friends', as a culturally rich expression, is used to refer to Chinese backpackers (Chen, Bao and Huang, 2014; Luo, Huang and Brown, 2015). Ecotourism (in Chinese, shentai lüyou), has obvious different cultural understandings in China compared to those in the West (Buckley et al., 2008; Ye and Xue, 2008). While Westerners see man and nature divided, Chinese view a unity between man and nature; thus, a lot of 


\section{Handbook on tourism and China}

relationships in ecotourism are redefined in the Chinese context. Largely driven by the cultural values of filial piety and devotion to family, some unique forms of tourism and industry phenomena, such as filial tourism, where children either pay to send or take their parents on holiday, emerge in China as distinctively culturally driven tourism phenomena (Wang et al., 2018).

Thus, it is time to reflect on China as a tourism research context. Such a context warrants more in-depth epistemological interrogations and paradigmatic reassessment. If we can refer to China as a context for knowledge creation, it should be a 'grand' or 'mega' context.

\section{TOURISM STUDY SUBJECTS IN CHINA}

As a relatively young study field, tourism has roughly about 40 years of development (Airey, 2015; Bao, Huang and Chen, 2019). In China, the study of tourism as an academic study has been in place since the opening up of the country in 1979 (Bao et al., 2019). Researchers have been contemplating on the tourism research development in China as a knowledge field (Huang and Chen, 2016a).

Back in 2008, Huang and Hsu (2008) reviewed 500 papers published in China's most prominent tourism research journal, the Tourism Tribune, from 2000 to 2005. They revealed that the research topics concentrated on the following areas:

- tourism attraction/resources/product development, management and protection;

- tourism planning;

- tourism industry development status and trends;

- ecotourism and sustainable tourism;

- tourism marketing and market analysis;

- hotel business environment and management; and

- basic concepts and theoretical issues in tourism and hospitality.

Following Huang and Hsu (2008), Hsu, Huang and Huang (2010) expanded the review scope to cover another major Chinese tourism journal, Tourism Science, together with Tourism Tribune and prolonged the review period from 2000 to 2008. In addition, they made a comparison between the Chinese tourism literature in the review and the literature on China tourism and hospitality as embodied in six top tourism and hospitality journals internationally. They found that the background disciplines of the Chinese literature are, in order of number of papers, business, urban and regional planning, economics, marketing, hotel and restaurant administration, parks and recreation, psychology, sociology, literature reviews, environmental studies, law, education, and others. In comparison, the English-language literature features disciplines such as, in order of number of papers, hotel and restaurant administration, psychology, business, parks and recreation, political science, sociology, marketing, urban and regional planning, and economics. Specifically, the research themes in the Chinese literature are:

- tourism resources/attractions/product development, management and protection (12.11 per cent); 
- hotel management (6.62 per cent);

- tourism marketing and market analysis (5.56 per cent);

- tourist behaviour (4.96 per cent);

- meetings, incentives, conferencing and exhibitions (MICE) (4.63 per cent);

- tourism economics (3.77 per cent);

- destination management (3.71 per cent);

- regional tourism cooperation and development (3.64 per cent);

- human resources management (3.11 per cent);

- tourism planning (2.91 per cent);

- ecotourism (2.78 per cent);

- and others (46.19 per cent).

Hsu et al. (2010) further observed that tourism researchers in China were increasingly embracing positivistic research paradigms; however, academic rigour and application of advanced methods in the tourism research community in China have yet to be improved.

Given the fast development in China's tourism research, Huang and Chen (2016a) selected all research articles published in the Tourism Tribune in 2015 and provided a cross-sectional snapshot of tourism research in China. Based on the review of 129 research articles published that year, they discovered that the topics follow 'tourist behaviour' $(n=22)$; 'destination image, branding, and marketing' $(n=12)$; 'tourism economics, forecasting and industry development' $(n=11)$; 'tourism marketing and market analysis' $(n=8)$; 'community tourism' $(n=7)$; 'tourism attraction management and admission ticketing' $(n=5)$; 'tourism law and legal issues' $(n=5)$; 'sustainable tourism' $(n=5)$; 'hotel studies' $(n=5)$; 'research review' $(n=5)$; 'special forms of tourism' $(n=4)$; and 'tourism safety' $(n=3)$ among others. With reference to previous review studies such as Huang and Hsu (2008) and Hsu et al. (2010), Huang and Chen (2016a) observed that there was a clear transition from industry supply-side issues to market-demand issues in the topic selection of tourism researchers in China.

Recently, Huang et al. (2019) reviewed 2078 research articles published in the Tourism Tribune from 2000 to 2015, aiming to identify the development trends of tourism research in China after the Millennium. The study reinforced the transition from industry supplyfocused issues to market-demand issues as a general trend. In general, regional tourism/ destination development and tourism planning, tourism consumer behaviours, tourism economics/forecasting and industry development, and tourism marketing and market analysis are the prominent themes of research. Specifically, regional tourism/destination development and tourism planning saw a declining trend in number during the periods 2000-05, 2005-10 and 2011-15. On the other hand, studies of tourism consumer behaviours experienced a surge over the years.

While the above-mentioned review studies represent those published in Englishlanguage journals and are easily accessible to international readers, there are a lot of review studies of a similar nature but in Chinese. Among these studies, Zhang et al.'s (2013) study may be the most comprehensive in its review scope so far. They reviewed a total of 16024 tourism academic papers published in major social science journals in China over a period of ten years (2003-12) and identified the following research themes for tourism research in China: 


\section{Handbook on tourism and China}

- tourism geography;

- tourism development of destination and region;

- tourism public management and industry management;

- tourism planning;

- tourism humanities;

- tourism marketing;

- tourism environment;

- tourism economics;

- tourism theory and research;

- tourism psychology;

- tourism education;

- tourism informatization and its application;

- tourism law; and

- tourism roads and transportation.

Very few research books have been dedicated to reviewing tourism research topics in China. An exception is Huang and Chen's (2016b) short, authored book, which critiqued the tourism scholarship in China in terms of the overall research institutions, themes and methodologies, philosophical and epistemological views of tourism, rural tourism, community participation and involvement in tourism, tourist market and behavioural studies, tourist attraction management, and tour guiding and interpretation. Despite this effort, Huang and Chen (2016b, p. xi) acknowledged that:

[there] exists a form of information asymmetry between tourism researchers in China and their international counterparts outside China. Whereas tourism researchers in China can mostly read and access tourism literature in English produced by the international tourism research community, the reverse is not the case. Many researchers outside China cannot access the tourism literature created in China in the Chinese language.

To a certain degree, the present Handbook is a continuation of Huang and Chen's (2016b) work.

\section{CHINESE TOURISM DISCOURSES}

It would be good to understand tourism in China and China as a grand context of tourism by elaborating on some tourism discourses in China. First, tourism is positioned as a 'strategic pillar' industry in China. Before the opening up of the People's Republic of China, tourism was part of foreign affairs after the Chinese Communist Party (CCP) gained power to govern the country in 1949. Between 1949 and 1979, tourism was socially and politically perceived as a bourgeois activity and thus domestic tourism by the grassroots was discouraged as a political discourse. Inbound tourism was restricted to some foreign diplomats and friends from countries friendly to China, or overseas Chinese who were supportive of the revolutionary causes of China. In 1978, when Deng Xiaoping decided to open up the country and started to reform the economic system, he delivered a series of speeches redefining the role of tourism in the country's economic development (Xiao, 2006). Tourism was then acknowledged as an economic sector that can contribute to the 
country's much-needed foreign exchange reserve. Furthermore, the hotel accommodation sector became the front line of utilizing foreign direct investment (FDI), mostly from those compatriot overseas Chinese businesspeople.

In the 1990s, tourism was further recognized for its contribution to the national economy. In 1999, to meet the needs of the growing domestic tourism demand, the central government implemented the 'Golden Weeks' holiday system (Yan and Zhang, 2010), instituting three, week-long national holidays for Chinese people.

After the turn of the Millennium, tourism in China was further recognized for its multiple functions beyond economic contributions (Huang, 2010). In the official discourses, tourism was also referred to as a force or means by which to create social harmony and promote political socialization (Zuo, Huang and Liu, 2016). Red tourism, as a unique politicized tourism form to promote the communist heritage sites and ideologies, has been endorsed and vigorously promoted by all levels of governments ( $\mathrm{Li}$ and $\mathrm{Hu}, 2008 ; \mathrm{Li}, \mathrm{Hu}$ and Zhang, 2010; Zhao and Timothy, 2015).

With the rapid socio-economic transformation in China, tourism's role in contributing to quality of life has been further reinforced. In 2013, the State Council promulgated the 'National Tourism and Leisure Guidelines', promoting a mass leisure society in China. The Guidelines have been interpreted as the embodiment of the Chinese government's more humanistic governance ideology.

Since 2014, Chinese outbound tourism has been leading the world in its total number of departures and total spend. Currently, China is the world's second largest economy. In 2018, China's gross domestic product (GDP) accounted for 15.9 per cent of the world's total. It is undeniable that in the world stage, Chinese outbound tourism represents a significant volume of service trade. Politically, Chinese outbound tourism could well be a demonstration of China's soft power (Tse, 2013; Xu, Wang and Song, 2020). Associated with this is China's Belt and Road Initiative (BRI) - a grand plan to connect Asia, Africa and Europe with a 'belt' of overland corridors and 'roads' of shipping lanes - and President Xi Jinping's advocacy for 'a community of shared future for mankind'. Some studies have found that the BRI has influenced the inbound tourist flows from those countries along the Belt and Road to China (Huang et al., 2019).

Urbanization has been a mega trend in China's transformation. At the end of 2012, for the first time, China saw more of its residents living in urban areas than in rural areas. Urbanization has exerted foundational influences on Chinese society. For thousands of years, Chinese culture and society had been mostly based on its rural social structure and traditions (Fei, Hamilton and Zheng, 1992). China has seen a lot of its rural villages emptied and dilapidated due to residents migrating to cities. This creates a great challenge for Chinese society to maintain its cultural traditions. The validity of the famous sociologist Fei Xiaotong's claim that 'Chinese society is fundamentally rural' has arguably been challenged for the first time.

Along with the urbanization trend is the rapid ageing of the population in China. At the end of 2017, 241 million citizens in China had reached the age of 60 or above, accounting for 17.3 per cent of China's total population. The number of senior citizens over 60 years old in China is expected to peak at 487 million, or nearly 35 per cent of the country's total population in 2050 (Chi, 2018), creating some social issues for the future. Tourism, however, may contribute to alleviating the social problems that come with an ageing society. It is observed that due to rapid urbanization and the increasingly alienated 


\section{Handbook on tourism and China}

post-modern urban life (Dann, 1977), Chinese adult children tend to take their parents on holiday (Wang et al., 2018). Such a phenomenon can be attributed to the multiple play of the social, cultural and economic forces.

In the face of rural societal change, the Chinese government has been implementing a national strategy called 'rural revitalization' (xiangcun zhenxing zhanlue), which sees its predecessor as the New Rural Area Construction Strategy. Tourism is perceived to play a significant role in its super-connectivity to other sectors like agriculture in implementing the rural revitalization strategy. Investment is being directed to rural areas for the construction of tourism-featured towns and villages. However, the effect is yet to be evaluated.

\section{CONCLUSIONS}

This chapter introduces the Handbook by providing some contextual discussions on tourism and China. It provides dialectic but critical viewpoints on tourism and China as dual contexts for understanding many pertinent issues in our world. Tourism has emerged as a distinctive knowledge field. When China is added as a context within which to study tourism, the distinctive nature of the context may prompt us to redefine the subject itself. It should be acknowledged that the complexities of both tourism and China justify the need to study them at the same time. And hence this book!

This chapter gives an overview of the tourism subject areas examined in China mostly by Chinese tourism researchers. Due to the information asymmetry between Chinese tourism researchers and their international, mostly English-speaking counterparts, as noted by Huang and Chen (2016b), the particularities of what has been researched in China in the field of tourism have been reviewed as part of this chapter.

This chapter also presents some tourism-related discourses alongside China's tourism development. These discourses will enable a better understanding of the underlying institutional and superstructural forces that influence tourism development in China. They also provide contextual understanding of the various issues included in the other chapters of this Handbook.

\section{REFERENCES}

Airey, D. (2015), '40 years of tourism studies - a remarkable story', Tourism Recreation Research, 40(1), 6-15.

Ateljevic, I., N. Morgan and A. Pritchard (2012), The Critical Turn in Tourism Studies: Creating an Academy of Hope, London: Routledge.

Bao, J., S.S. Huang and G. Chen (2019), 'Forty years of China tourism research: reflections and prospects', Journal of China Tourism Research, 15(3), 283-94.

Buckley, R., C. Cater, L. Zhong and T. Chen (2008), 'Shengtai luyou: cross-cultural comparison in ecotourism', Annals of Tourism Research, 35(4), 945-68.

Chen, G., J. Bao and S.S. Huang (2014), 'Segmenting Chinese backpackers by travel motivations', International Journal of Tourism Research, 16(4), 355-67.

Chi, D. (2018), 'China's elderly population continues to rise, with 241 million now 60 or over', gbtimes.com, 27 February 2018, accessed 12 September 2019 at https:/gbtimes.com/chinas-elderly-population-continues-torise.

Dann, G.M.S. (1977), 'Anomie, ego-enhancement and tourism', Annals of Tourism Research, 4(4), $184-94$.

Fei, X., G.G. Hamilton and W. Zheng (1992), From the Soil: The Foundations of Chinese Society. A Translation of Fei Xiaotong's Xiangtu Zhongguo, Berkeley, CA: University of California Press. 
Foucault, M. (1980), Power/Knowledge: Selected Interviews and Other Writings, 1972-1977, Brighton, UK: Harvester Press.

Hofstede, G.H. (1980), Culture's Consequences: International Differences in Work-Related Values, Beverly Hills, CA: Sage.

Hsu, C.H.C. and S.S. Huang (2016), 'Reconfiguring Chinese cultural values and their tourism implications', Tourism Management, 54, 230-42.

Hsu, C.H.C., J. Huang and S.S. Huang (2010), 'Tourism and hospitality research in mainland China: trends from 2000 to 2008', in D. Pearce and R. Butler (eds), Tourism Research: A 20:20 Vision, Oxford: Goodfellow Publishers, pp. 147-60.

Huang, S.S. (2010), 'Evolution of China's tourism policies', International Journal of Tourism Policy, 3(1), $78-84$.

Huang, S.S. and G. Chen (2016a), 'Current state of tourism research in China', Tourism Management Perspectives, 20, 10-18.

Huang, S.S. and G. Chen (2016b), Tourism Research in China: Themes and Issues, Bristol: Channel View Publications.

Huang, S.S., G. Chen, X. Luo and J. Bao (2019), 'Evolution of tourism research in China after the Millennium: changes in research themes, methods and researchers', Journal of China Tourism Research, 15(3), 420-34.

Huang, S.S. and J. Crotts (2019), 'Relationships between Hofstede's cultural dimensions and tourist satisfaction: a cross-country cross-sample examination', Tourism Management, 72, 232-41.

Huang, S.S. and C.H.C. Hsu (2008), 'Recent tourism and hospitality research in China', International Journal of Hospitality and Tourism Administration, 9(3), 267-87.

Huang, X., Y. Han, X. Gong and X. Liu (2019), 'Does the Belt and Road Initiative stimulate China's inbound tourist market? An empirical study using the gravity model with a DID method', Tourism Economics, doi: $10.1177 / 1354816619867577$.

Jafari, J. and J.R.B. Ritchie (1981), 'Toward a framework for tourism education: problems and prospects', Annals of Tourism Research, 8(1), 13-34.

Leiper, N. (1979), 'The framework of tourism: towards a definition of tourism, tourist, and the tourist industry', Annals of Tourism Research, 6(4), 390-407.

Li, F. and C. Ryan (2015), 'Chinese tourists' motivations and satisfaction of visiting North Korea', Asia Pacific Journal of Tourism Research, 20(12), 1313-31.

Li, F.M.S. (2008), 'Culture as a major determinant in tourism development of China', Current Issues in Tourism, 11(6), 492-513.

Li, Y. and Z. Hu (2008), 'Red tourism in China', Journal of China Tourism Research, 4(2), 156-71.

Li, Y., Z. Hu and C. Zhang (2010), 'Red tourism: sustaining communist identity in a rapidly changing China', Journal of Tourism and Cultural Change, 8(2), 101-19.

Luo, X., S.S. Huang and G. Brown (2015), 'Backpacking in China: a netnographic analysis of donkey friends' travel behaviour', Journal of China Tourism Research, 11(1), 67-84.

McKercher, B. and V. Tung (2015), 'Publishing in tourism and hospitality journals: is the past a prelude to the future', Tourism Management, 50, 306-15.

Smith, S.L.J. (2017), Practical Tourism Research (2nd edition), Wallingford, UK: CABI.

Sorell, T. (2013), Scientism: Philosophy and the Infatuation with Science, London: Routledge.

Tourism Research Australia (2019), 'Latest international visitor survey (IVS) results: year ending September 2019', accessed 12 September 2019 at https://www.tra.gov.au/International/international-tourism-results.

Tourism WA (2019), 'International visitation - fast facts: year ending March 2019', accessed 12 September 2019 at https://www.tourism.wa.gov.au/Publications\%20Library/Research\%20and\%20reports/2019/YE\%20 March $\% 202019 /$ IVS $\% 20$ Fast $\% 20$ Facts $\% 20$ YE $\% 20$ Mar $\% 2019$.pdf.

Tribe, J. (1997), 'The indiscipline of tourism', Annals of Tourism Research, 24(3), 638-57.

Tribe, J. (2001), 'Research paradigms and the tourism curriculum', Journal of Travel Research, 39(4), 442-8.

Tribe, J. (2006), 'The truth about tourism', Annals of Tourism Research, 33(2), 360-81.

Tse, T.S.M. (2013), 'Chinese outbound tourism as a form of diplomacy', Tourism Planning and Development, 10(2), 149-58.

Urry, J. (2002), The Tourist Gaze: Leisure and Travel in Contemporary Societies (2nd edition), London: Sage.

Wang, Y., L. Yi, M. Wu, P. Pearce and S.S. Huang (2018), 'Examining Chinese adult children's motivations for traveling with their parents', Tourism Management, 69, 422-33.

Wen, J., S.S. Huang and T. Ying (2019), 'Relationships between Chinese cultural values and tourist motivations: a study of Chinese tourists visiting Israel', Journal of Destination Marketing and Management, 14, 1-10.

Xiao, H. (2006), 'The discourse of power: Deng Xiaoping and tourism development in China', Tourism Management, 27(5), 803-14.

Xu, H., K. Wang and Y.M. Song (2020), 'Chinese outbound tourism and soft power', Journal of Policy Research in Tourism, Leisure and Events, 12(1), 34-49.

Yan, Q.Y. and H.Q. Zhang (2010), 'The determinants of the 1999 and 2007 Chinese Golden Holiday System: a content analysis of official documentation', Tourism Management, 31(6), 881-90. 


\section{Handbook on tourism and China}

Ye, W. and X. Xue (2008), 'The differences in ecotourism between China and the West', Current Issues in Tourism, 11(6), 567-86.

Ying, T. and J. Wen (2019), 'Exploring the male Chinese tourists' motivation for commercial sex when travelling overseas: scale construction and validation', Tourism Management, 70, 479-90.

Zhang, L. (2008), 'Review on the definitions and concept of tourism currently popular in the world - recognition of the nature of tourism', Tourism Tribune, 23(1), 86-91.

Zhang, L., C. Lan, F. Qi and P. Wu (2013), 'Development pattern, classification and evaluation of the tourism academic community in China in the last ten years: from the perspective of big data of articles of tourism academic journals', Tourism Tribune, 28(10), 114-25.

Zhao, S. and D.J. Timothy (2015), 'Governance of red tourism in China: perspectives on power and guanxi', Tourism Management, 46, 489-500.

Zuo, B., S.S. Huang and L. Liu (2016), 'Tourism as an agent of political socialisation', International Journal of Tourism Research, 18(2), 176-85. 